\title{
PENGARUH KEHARMONISAN KELUARGA DAN MOTIVASI BELAJAR TERHADAP HASIL BELAJAR IPA KELAS IV SD NEGERI SEKECAMATAN KEBUMEN TAHUN AJARAN 2020/2021
}

\author{
Arief Muhamad Fachrur Rozi ${ }^{1}$, Kartika Chrysti Suryandari ${ }^{2}$, Muhamad \\ Chamdani $^{3}$
}

Universitas Sebelas Maret

ariefmuhamad14@gmail.com

\section{Article History}

accepted $1 / 11 / 2021$

approved 1/12/2021

published 31/12/2021

\begin{abstract}
The study aimed to determine positive and significant effects between: (1) family harmony and natural science learning outcomes, (2) learning motivation and natural science learning outcomes, and (3) family harmony and learning motivation on natural science learning outcomes to fourth grade students of public elementary schools in Kebumen Sub-district in academic year of 2020/2021. It was correlational quantitative method with multiple regression analysis. Sampling method was random sampling technique. The results showed: (1) there was a positive and significant effect between family harmony and natural science learning with contribution of $66.5 \%$; (2) there was a positive and significant effect between learning motivation and natural science learning with contribution of $25.9 \%$; (3) there was a positive, simultaneous, and significant effect between family harmony and learning motivation on science learning with contribution of $92.4 \%$. It concludes that there is positive effect of the family harmony and learning motivation on the natural science learning outcomes to fourth grade students of public elementary schools in Kebumen Sub-district in academic year of 2020/2021.
\end{abstract}

Keywords: family harmony, high learning motivation, natural science learning outcomes Abstrak

Penelitian ini bertujuan untuk membuktikan ada tidaknya: (1) pengaruh positif signifikan antara keharmonisan keluarga dengan hasil belajar IPA; (2) pengaruh positif signifikan antara motivasi belajar dengan hasil belajar IPA; (3) pengaruh positif signifikan antara keharmonisan keluarga dan motivasi belajar dengan hasil belajar IPA kelas IV SDN se-Kecamatan Kebumen tahun ajaran 2020/2021. Penelitian ini merupakan penelitian kuantitatif dengan korelasi menggunakan analisis regresi berganda. Pengambilan sampel dilakukan dengan teknik random sampling. Hasil penelitian menunjukkan: (1) terdapat pengaruh positif dan signifikan antara keharmonisan keluarga dengan hasil belajar IPA sebesar 66,5\%; (2) terdapat pengaruh positif dan signifikan antara motivasi belajar dengan hasil belajar IPA sebesar 25,9\%; (3) terdapat pengaruh positif dan signifikan antara keharmonisan keluarga dan motivasi belajar secara simultan dengan hasil belajar IPA sebesar 92,4\%. Berdasarkan analisis dan hasil penelitian dapat disimpulkan bahwa terdapat pengaruh positif antara keharmonisan keluarga dan motivasi belajar terhadap hasil belajar IPA kelas IV SDN se-Kecamatan Kebumen tahun ajaran 2020/2021 secara bersama-sama maupun terpisah.

Kata Kunci: keharmonisan keluarga, motivasi belajar, hasil belajar IPA 


\section{PENDAHULUAN}

Pendidikan menjadi salah satu hal yang sangat utama bagi setiap manusia. Melalui pendidikan, setiap orang bisa mencapai keinginan yang di cita-citakan. Pada tingkatan sekolah dasar, pendidikan menjadi hal yang sangat dibutuhkan oleh siswa untuk bekal kedepannya. Guna mencapai pendidikan yang baik, perlu adanya kolaborasi yang baik antara siswa, guru, maupun orang tua siswa. Di lingkungan sekolah, guru perlu membangun kerjasama dan memberikan motivasi yang membangun kepada siswa. Di lingkungan rumah, keharmonisan keluarga sangat mempengaruhi siswa dalam belajar yang berdampak pada hasil belajar siswa tersebut. Selanjutnya, karakter siswa sekolah dasar di abad ke-21 yaitu perilaku belajarnya sangat tergantung pada mesin pencari google yang mana perlu adanya pengawasan dari orang tua, maka siswa membutuhkan keharmonisan keluarga dalam perkembangannya.

Beberapa usaha untuk mewujudkan suatu kehidupan keluarga yang harmonis antara lain dengan membina hubungan baik antar sesama anggota dalam keluarga yang bernaung di dalam suatu rumah tangga. Soerjono (Ermawati, 2016) menyebutkan bahwa keluarga yang harmonis adalah keluarga yang dibina atas dasar kesesuaian dan keserasian hubungan diantara anggota keluarga. Hal tersebut meliputi hubungan baik antara ayah dengan ibu, ayah dengan anak, ibu dengan anak, dan antarsesama anak dalam satu keluarga. Disamping itu mereka harus saling mengerti dan mau melaksanakan kewajiban sesuai dengan tanggung jawabnya serta menghindarkan diri dari perbuatan yang tidak baik. Dengan demikian akan tercipta suasana keluarga seperti ini dapat membuat tenang semua anggota keluarga dan betah tinggal dirumah, terutama bagi anak. Dengan terciptanya keharmonisan keluarga maka dimungkinkan anak lebih bersemangat dan bergairah dalam kegiatan belajarnya. Beberapa indikator dari keharmonisan keluarga yang dapat memberikan pengaruh terhadap hasil belajar siswa komitmen, apresiasi dan afeksi, kasih sayang antar anggota keluarga, komunikasi yang positif, waktu berkualitas bersama keluarga, menanamkan nilai-nilai spiritual dan agama.

Motivasi sangat terkait dalam belajar, dengan motivasi siswa menjadi tekun dalam proses belajar, dengan motivasi juga kualitas hasil belajar siswa kemungkinan dapat diwujudkan. Siswa yang dalam proses belajar mempunyai motivasi kuat dan jelas, pasti akan tekun dan berhasil dalam belajarnya. Menurut Sadirman (Susanti, 2015) siswa yang mempunyai motivasi belajar yang kuat disebabkan karena ada tiga fungsi motivasi yaitu mendorong manusia untuk berbuat dan melakukan aktivitas, menentukan arah perbuatannya, serta menyeleksi perbuatannya. Sehingga perbuatan siswa senantiasa selaras dengan tujuan belajar yang akan dicapainya. Menurut Wardiyati (Susanti, 2015), motivasi sangat menentukan prestasi belajar. Bagaimanapun sempurnanya metode yang digunakan oleh guru, namun jika motivasi belajar siswa kurang atau tidak ada, maka siswa tidak akan belajar dan akibatnya hasil belajarnya pun tidak akan tercapai. Beberapa indikator dari motivasi belajar yang dapat memberikan pengaruh terhadap hasil belajar siswa (1) adanya hasrat dan keinginan berhasil, (2) adanya harapan dan cita-cita masa depan, (3) adanya penghargaan dalam belajar, (4) adanya kegiatan menarik dalam belajar, (5) adanya lingkungan kondusif, (6) ulet dalam menghadapi kesulitan.

Hasil belajar merupakan hal yang tidak dapat dipisahkan dari proses belajar yang dijalani oleh seorang siswa di bangku pendidikan. Menurut Supratiknya (dalam Widodo, 2013) mengemukakan bahwa hasil belajar yang menjadi objek penilaian kelas berupa kemampuan-kemampuan baru yang diperoleh siswa setelah mereka mengikuti proses belajar-mengajar tentang mata pelajaran tertentu. Tinggi rendahnya prestasi belajar siswa yang menunjukkan tingkat keberhasilan belajarnya, dapat dipengaruhi oleh beberapa faktor baik dari dalam (internal) maupun dari luar (eksternal) siswa. Beberapa faktor yang sangat mempengaruhi hasil belajar seorang siswa adalah keharmonisan keluarga dan motivasi belajar. IPA sebagai salah satu mata pelajaran di sekolah dapat 
memberikan peranan dan pengalaman bagi siswa. Hasil belajar IPA pun dapat dipengaruhi oleh keharmonisan keluarga dan motivasi belajar siswa tersebut.

Berdasarkan hasil analisis data dapat diketahui untuk dapat meningkatkan hasil belajar, dibutuhkan perhatian terhadap faktor-faktor yang mempengaruhinya, diantaranya yaitu keluarga harmonis (faktor eksternal) dan motivasi belajar tinggi (faktor internal).

Tujuan penelitian ini yaitu (1) Membuktikan adanya pengaruh positif dan signifikan antara keluarga harmonis terhadap hasil belajar IPA; (2) Membuktikan adanya pengaruh positif dan signifikan antara motivasi belajar tinggi terhadap hasil belajar IPA; dan (3) Membuktikan adanya pengaruh positif dan signifikan antara kelurga harmonis dan motivasi belajar tinggi terhadap hasil belajar IPA kelas IV SDN se-Kecamatan Kebumen tahun ajaran 2020/2021.

\section{METODE}

Desain penelitian yang digunakan dalam penelitian ini adalah penelitian kuantitatif dengan korelasi menggunakan analisis regresi berganda. Penelitian korelasi adalah penelitian yang melibatkan hubungan satu atau lebih variabel dengan satu atau lebih variabel lain (Purwanto, 2012: 177). Menurut Sugiyono (2013: 192) analisis regresi berganda adalah regresi yang mempunyai satu variabel dependent dan dua atau lebih variabel independent. Populasi penelitian ini yaitu siswa kelas IV SDN se-Kecamatan Kebumen sejumlah 1400 siswa dengan sampel sebanyak 330 siswa di tigabelas SDN di Kecamatan Kebumen. Teknik pengambilan sampel yang digunakan yaitu random sampling.

Teknik pengumpulan data yang digunakan pada penelitian ini yaitu tes dan angket. Tes digunakan untuk mengumpulkan data hasil belajar IPA dan angket untuk mendapatkan data keluarga harmonis dan motivasi belajar tinggi. Instrumen penelitian terlebih dahulu diuji validitas dan reliabilitas sebelum digunakan untuk penelitian. Pengumpulan data untuk uji instrument dilakukan pada 44 siswa kelas IV di dua sekolah dasar yang tidak termasuk sampel.

Uji prasyarat data dalam penelitian ini yaitu uji normalitas data, uji linieritas data, dan uji multikolinieritas. Setelah data dapat memenuhi prasyarat yang ditentukan, data akan dianalisis menggunkan analisis regresi berganda, analisis korelasi berganda, dan sumbangan efektif.

\section{Uji Persyaratan Analisis}

\section{HASIL DAN PEMBAHASAN}

Penelitian dilakukan dengan memberikan angket keluarga harmonis dan motivasi belajar tinggi serta soal tes hasil belajar IPA kelas IV SD yang menjadi sampel penelitian. Uji prasyarat data pada penelitian ini telah terpenuhi yaitu data berdistribusi normal, data linear, dan data multikolinieritas.

Pada penelitian ini diperoleh data berupa nilai Asymp. Sig. (2-tailed) pada ketiga variabel yaitu variabel keluarga harmonis 0,402 , motivasi belajar tinggi 0,422 , dan hasil belajar IPA 0,439. Dari data tersebut, dapat diketahui bahwa signifikansi $>0,05$. Oleh karena itu, dapat disimpulkan bahwa Ho diterima atau artinya variabel keharmonisan keluarga, motivasi belajar tinggi, dan hasil belajar IPA berasal dari populasi yang berdistribusi normal.

Tabel 1. Rangkuman Hasil Uji Linearitas

\begin{tabular}{llll}
\hline Variabel & F & Sig. & Keterangan \\
\hline Hasil Belajar*Keluarga harmonis & 1,247 & 0,168 & Linear \\
\hline Hasil Belajar*Motivasi belajar tinggi & 1,448 & 0,064 & Linear \\
\hline
\end{tabular}

Berdasarkan uji linearitas yang telah dilakukan, dapat diketahui bahwa pada uji linearitas variabel hasil belajar IPA dan keluarga harmonis didapatkan nilai $p$ value Deviation from Linearity sebesar 0,168 . Nilai signifikansi tersebut lebih dari $0,05(0,168$ 
$>0,05)$ sehingga didapatkan hasil yaitu terima $\mathrm{H} 0$ yang artinya terdapat hubungan linear antara hasil belajar IPA dengan variabel keluarga harmonis. Untuk hasil belajar IPA dan motivasi belajar tinggi diperoleh nilai $p$ value Deviation from Linearity sebesar 0,064 . Nilai signifikansi tersebut lebih dari $0,05(0,064>0,05)$ sehingga dapat didapatkan hasil yaitu terima $\mathrm{HO}$ atau terdapat hubungan linear antara hasil belajar IPA dengan variabel motivasi belajar tinggi.

Tabel 2. Hasil Uji Multikolinearitas $\mathrm{X}_{1}$ dan $\mathrm{X}_{2}$

\begin{tabular}{lccc}
\hline \multirow{2}{*}{ Variabel/Model } & \multicolumn{2}{c}{ Collinearity Statistic } & \multirow{2}{*}{ Keterangan } \\
\cline { 2 - 3 } & Tolerance & VIF & \\
\hline Keluarga harmonis & 0,306 & 3,270 & Tidak terjadi multikolinearitas \\
\hline Motivasi belajar tinggi & 0,306 & 3,270 & Tidak terjadi multikolinearitas \\
\hline
\end{tabular}

Uji multikolinearitas menunjukkan bahwa setiap variabel bebas (independent) memiliki nilai tolerance 0,306 dan nilai VIF 3,270 sehingga dapat disimpulkan bahwa tidak terjadi multikolinearitas dalam variabel keluarga harmonis dan motivasi belajar tinggi pada model regresi linear berganda karena nilai tolerance $>0,10$ serta nilai VIF $<$ 10,00 .

\section{Uji Hipotesis}

Setelah uji prasyarat analisis data terpenuhi, maka dilanjutkan melakukan analisis data uji hipotesis dengan hasil sebagai berikut.

Tabel 3. Hasil Uji Regresi Berganda dengan Data Masing-Masing

\section{Coefficients $^{\mathrm{a}}$}

\begin{tabular}{|c|c|c|c|c|c|c|}
\hline \multirow{2}{*}{\multicolumn{2}{|c|}{ Model }} & \multicolumn{2}{|c|}{$\begin{array}{l}\text { Unstandardized } \\
\text { Coefficients }\end{array}$} & \multirow{2}{*}{$\begin{array}{c}\text { Standardized } \\
\text { Coefficients } \\
\text { Beta }\end{array}$} & \multirow[t]{2}{*}{$\mathrm{T}$} & \multirow[t]{2}{*}{ Sig. } \\
\hline & & $\mathrm{B}$ & Std. Error & & & \\
\hline \multirow{3}{*}{1} & (Constant) & $-50,536$ & 2,014 & & $-25,093$ & ,000 \\
\hline & Keluarga harmonis & 1,049 &, 041 & ,703 & 25,479 &, 000 \\
\hline & Motivasi belajar tinggi & 461 & ,043 & ,294 & 10,649 &, 000 \\
\hline
\end{tabular}

a. Dependent Variable: Hasil Belajar

Berdasarkan tabel 3, diketahui bahwa pada variabel keluarga harmonis diperoleh nilai $t_{\text {hitung }}=25,479>t_{\text {tabel }}=1,967$ dengan sig. 0,000 $<0,05$. Jadi dapat disimpulkan bahwa Ho1 ditolak yang artinya keluarga harmonis berpengaruh signifikan terhadap hasil belajar IPA kelas IV SDN se-Kecamatan Kebumen tahun ajaran 2020/2021. Untuk motivasi belajar tinggi memiliki nilai $t_{\text {hitung }}=10,649>t_{\text {tabel }}=1,967$ dengan sig. $0,000<$ 0,05 . Oleh karena itu dapat di simpulkan bahwa $\mathrm{Ho} 2$ ditolak yang artinya motivasi belajar tinggi berpengaruh signifikan terhadap hasil belajar IPA kelas IV SDN se-Kecamatan Kebumen tahun ajaran 2020/2021.

Tabel 4. Hasil Uji Regresi Berganda secara Simultan

\begin{tabular}{|c|c|c|c|c|c|c|}
\hline \multicolumn{7}{|c|}{ ANOVA $^{a}$} \\
\hline Model & & Sum of & $d f$ & Mean Square & $\mathrm{F}$ & Sig. \\
\hline \multirow{3}{*}{1} & Regression & 55506,480 & 2 & 27753,240 & 19,863 &, $000^{\mathrm{b}}$ \\
\hline & Residual & 4540,883 & 325 & 13,972 & & \\
\hline & Total & 60047,363 & 327 & & & \\
\hline
\end{tabular}

a. Dependent Variable: Hasil Belajar

b. Predictors: (Constant), Motivasi belajar tinggi, Keluarga harmonis 
Berdasarkan tabel 4, diketahui bahwa nilai $F_{\text {hitung }}=19,863>F_{\text {tabel }}=3,023(\mathrm{df}=326$, taraf kesalahan $5 \%$ ). Nilai signifikansi yang diperoleh yaitu $0,000<0,05$. Hasil tersebut menunjukkan bahwa keluarga harmonis dan motivasi belajar tinggi secara bersamasama berpengaruh signifikan terhadap hasil belajar IPA kelas IV SDN se-Kecamatan Kebumen tahun 2020/2021.

Tabel 5. Hasil Uji Korelasi Correlations

\begin{tabular}{|c|c|c|c|c|c|}
\hline \multicolumn{3}{|c|}{ Control Variables } & $\mathrm{KH}$ & \multirow{2}{*}{$\begin{array}{r}\mathrm{MB} \\
, 833\end{array}$} & \multirow{2}{*}{$\begin{array}{l}\text { HB } \\
, 948\end{array}$} \\
\hline \multirow{9}{*}{- none-a } & & Correlation & 1,000 & & \\
\hline & $\mathrm{KH}$ & Significance (2-tailed) & 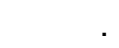 & 000 & 000 \\
\hline & & df & 0 & 326 & 326 \\
\hline & & Correlation & ,833 & 1,000 & ,879 \\
\hline & MB & Significance (2-tailed) & ,000 & & 000 \\
\hline & & $\mathrm{df}$ & 326 & 0 & 326 \\
\hline & & Correlation & ,948 & 879 & 1,000 \\
\hline & $\mathrm{HB}$ & Significance (2-tailed) & ,000 & ,000 & \\
\hline & & df & 326 & 326 & 0 \\
\hline
\end{tabular}

Berdasarkan tabel 5 di atas, dapat diketahui bahwa antara keluarga harmonis dengan hasil belajar IPA diperoleh $r_{\text {hitung }}=0,948>r_{\text {tabel }}(\mathrm{df}=326)=0,108$ maka Ho1 ditolak yang berarti terdapat korelasi positif antara variabel keluarga harmonis terhadap hasil belajar IPA. Untuk motivasi belajar tinggi dengan hasil belajar IPA memiliki nilai $r_{\text {hitung }}=0,879>r_{\text {tabel }}(d f=326)=0,108$ maka Ho2 ditolak yang berarti terdapat korelasi positif antara variabel motivasi belajar tinggi terhadap hasil belajar IPA.

Tabel 6. Hasil Uji Korelasi Berganda Model Summary

\begin{tabular}{ccccr}
\hline Model & $\mathrm{R}$ & $\begin{array}{c}\mathrm{R} \\
\text { Square }\end{array}$ & $\begin{array}{c}\text { Adjusted } \mathrm{R} \\
\text { Square }\end{array}$ & $\begin{array}{c}\text { Std. Error } \\
\text { of the } \\
\text { Estimate }\end{array}$ \\
\hline 1 &, $961^{\mathrm{a}}$ &, 924 &, 924 & 3,738 \\
\hline
\end{tabular}

a. Predictors: (Constant), Keluarga Harmonis, Motivasi belajar tinggi

Berdasarkan tabel 6 di atas, dapat diketahui bahwa nilai $r_{\text {hitung }}=0,961>r_{\text {tabel }}(\mathrm{df}=$ $326)=0,108$ yang artinya tolak Ho atau terdapat korelasi positif antara variabel keluarga harmonis dan motivasi belajar tinggi terhadap hasil belajar IPA.

Pengaruh Keluarga Harmonis terhadap Hasil Belajar IPA

Pengaruh keluarga harmonis terhadap hasil belajar IPA dalam penelitian ini menggunakan analisis regresi berganda parsial di aplikasi SPSS versi 21. Dalam menganalisis diperlukan melakukan uji hipotesis, sama halnya dengan penelitian ini yaitu hipotesisnya berupa terdapat pengaruh positif antara keluarga harmonis terhadap hasil belajar IPA kelas IV SDN Se-Kecamatan Kebumen tahun ajaran 2020/2021.

Hasil pengujian koefisien regresi berganda menunjukkan hasil bahwa keluarga harmonis mempunyai nilai $t_{\text {hitung }}=25,479>t_{\text {tabel }}=1,967$ dan nilai signifikansi $0,000<$ 0,05 , yang artinya Ho1 ditolak dalam arti lain keluarga harmonis berpengaruh signifikan terhadap hasil belajar IPA kelas IV SDN se-Kecamatan Kebumen tahun ajaran 2020/2021. Hasil pengujian korelasi berganda menunjukkan hasil bahwa variabel keluarga harmonis mempunyai nilai $r_{\text {hitung }}=0,948>r_{\text {tabel }}(d f=326)=0,108$ sehingga tolak Ho1 atau terdapat korelasi positif antara variabel keluarga harmonis terhadap hasil belajar IPA. Koefisien korelasi sebesar 0,948 menunjukkan terdapat hubungan yang 
kuat sekali (interval koefisien 0,91-0,99) antara variabel keluarga harmonis dan hasil belajar IPA.

Berdasarkan penelitian dan perhitungan yang telah dijelaskan di atas, diketahui bahwa keluarga harmonis berpengaruh positif dan signifikan terhadap hasil belajar IPA kelas IV SDN se-Kecamatan Kebumen tahun ajaran 2020/2021. Oleh karena itu, apabila semakin tinggi keharmonisan keluarga, maka semakin tinggi pula hasil belajar IPA-nya. Adapun sebaliknya, apabila keluarga tidak harmonis, maka hasil belajar IPA-nya rendah.

Hasil penelitian ini sejalan dengan penelitian yang dilakukan oleh Rahmawati (2015) dimana variabel keharmonisan keluaga memiliki $t_{\text {hitung }}$ sebesar 4,443 $>t_{\text {tabel }} 2,037$ dan nilai signifikannya $<0,05$, yaitu 0,000 yang artinya ada pengaruh yang signifikan antara keluarga harmonisdengan hasil belajar siswa kelas V SD Negeri Kradenan tahun 2014/2015.

Keharmonisan keluarga memiliki peranan yang penting dalam tumbuh kembang seseorang. Menurut Marmin (2013), seorang anak atau remaja yang dibesarkan dalam lingkungan sosial keluarga yang tidak baik atau disharmoni keluarga, maka resiko anak mengalami gangguan kepribadian menjadi berkepribadian antisosial dan berperilaku menyimpang lebih besar dibandingkan dengan anak yang dibesarkan dalam keluarga sehat atau harmonis (sakinah). Untuk mewujudkan keluarga yang harmonis ada beberapa hal yang harus diusahakan oleh setiap anggota keluarga, antara lain: komitmen, apresiasi dan afeksi, kasih sayang antar anggota keluarga, komunikasi yang positif, waktu berkualitas bersama keluarga, menanamkan nilai-nilai spiritual dan agama. Apabila keharmonisan tercipta dalam sebuah keluarga sehingga menimbulkan perasaan tenang dan damai setiap penghuninya maka akan melahirkan situasi yang sangat kondusif untuk belajar dengan tenang. Hal tersebut akan berdampak pada prestasi belajar siswa.

Berdasarkan penelitian dan perhitungan yang telah dilakukan, dapat disimpulkan bahwa keluarga harmonis berpengaruh positif dan signifikan terhadap hasil belajar siswa. Hasil penelitian ini sudah sesuai dengan teori dan didukung pula oleh penelitian yang relevan hasil penelitian. Oleh karena itu, hasil penelitian ini adalah keluarga harmonis berpengaruh positif dan signifikan terhadap hasil belajar IPA Kelas IV SDN SeKecamatan Kebumen tahun ajaran 2020/2021.

\section{Pengaruh Motivasi Belajar Tinggi terhadap Hasil Belajar IPA}

Pengaruh motivasi belajar tinggi terhadap hasil belajar IPA dalam penelitian ini menggunakan analisis regresi berganda parsial di aplikasi SPSS versi 21 . Di dalam menganalisis diperlukan melakukan uji hipotesis, sama halnya dengan penelitian ini yaitu hipotesisnya berupa terdapat pengaruh positif antara motivasi belajar tinggi terhadap hasil belajar IPA kelas IV SDN Se-Kecamatan Kebumen tahun ajaran 2020/2021.

Hasil pengujian koefisien regresi sederhana menunjukkan hasil bahwa nilai $t_{\text {hitung }}$ $=10,649>t_{\text {tabel }}=1,967$ dan nilai signifikansi $0,000<0,05$, yang artinya Ho2 ditolak dalam arti lain motivasi belajar tinggi berpengaruh signifikan terhadap hasil belajar IPA kelas IV SDN se-Kecamatan Kebumen tahun ajaran 2020/2021. Berdasarkan uji korelasi berganda menujukkan hasil bahwa variabel motivasi belajar tinggi mempunyai nilai $\mathrm{r}_{\text {hitung }}$ $=0,879>r_{\text {tabel }}(d f=326)=0,108$ sehingga tolak Ho2 atau terdapat korelasi positif antara variabel motivasi belajar tinggi terhadap hasil belajar IPA. Koefisien korelasi sebesar 0,879 menunjukkan terdapat hubungan yang sangat kuat (interval koefisien 0,71-0,90) antara variabel motivasi belajar tinggi dan hasil belajar IPA.

Berdasarkan penelitian dan perhitungan yang telah dijelaskan di atas, diketahui bahwa terdapat pengaruh positif secara signifikan antara motivasi belajar tinggi dengan hasil belajar IPA kelas IV SDN se-Kecamatan Kebumen tahun ajaran 2020/2021. Oleh karena itu, apabila semakin tinggi motivasi belajarnya, maka semakin tinggi pula hasil belajar IPA-nya. Adapun sebaliknya, apabila motivasi belajar rendah, maka hasil belajar IPA-nya rendah. 
Nugraheni (2014) menyatakan bahwa motivasi belajar berpengaruh positif dan signifikan terhadap prestasi belajar siswa kelas III SD se-gugus Sinduharjo Sleman dengan nilai $t_{\text {hitung }}=2,035$, dengan $p=0,044$, $t_{\text {tabel }}=1,659$, maka $t_{\text {hitung }}>t_{\text {tabel }}$ dan $p<$ 0,05 . Selain itu, Kurnia (2016) juga melakukan penelitian tentang pengaruh motivasi belajar terhadap hasil belajar seni musik yang hasilnya motivasi belajar memiliki pengaruh yang signifikan terhadap hasil belajar seni musik dengan $t_{\text {hitung }} 9.057>t_{\text {tabel }}$ 1.979 (df 127). Kurnia (2016) mengemukakan bahwa motivasi belajar akan mampu memengaruhi hasil belajar seni musik siswa kelas IV SD Dabin I Kecamatan Todanan Kabupaten Blora.

Motivasi dalam belajar merupakan salah satu hal yang perlu dibangkitkan dalam upaya pembelajaran di sekolah. Motivasi belajar yang dimiliki siswa dalam setiap kegiatan pembelajaran sangat berperan untuk meningkatkan prestasi belajar siswa dalam mata pelajaran tertentu. Siswa yang bermotivasi tinggi dalam belajar memungkinkan akan memperoleh prestasi belajar yang tinggi pula, artinya semakin tinggi motivasinya, semakin intensitas usaha dan upaya yang dilakukan, maka semakin tinggi prestasi belajar yang diperolehnya. Sebaliknya, jika motivasi belajar rendah dalam belajar memungkinkan akan memperoleh prestasi belajar yang rendah pula. Hamalik (2015: 108) mengungkapkan pendapatnya bahwa motivasi dalam belajar memiliki tiga fungsi: pertama, mendorong timbulnya tingkah laku atau perbuatan. Tanpa motivasi tidak akan timbul perbuatan seperti belajar. Kedua, motivasi sebagai pengarah, artinya mengarahkan perbuatan kepada pencapaian tujuan yang diinginkan. Ketiga, motivasi sebagai penggerak, artinya besar kecilnya motivasi akan menentukan cepat atau lambatnya suatu pekerjaan.

Berdasarkan penelitian dan perhitungan yang telah dilakukan, dapat diketahui bahwa motivasi belajar tinggi berpengaruh positif dan signifikan terhadap hasil belajar IPA siswa. Hasil penelitian ini sesuai dengan teori dan didukung pula oleh penelitian yang relevan dengan hasil penelitian. Oleh karena itu, hasil penelitian ini adalah terdapat pengaruh positif dan signifikan antara motivasi belajar tinggi terhadap hasil belajar IPA kelas IV SDN Se-Kecamatan Kebumen tahun ajaran 2020/2021.

\section{Pengaruh Keluarga Harmonis dan Motivasi Belajar Tinggi terhadap Hasil Belajar IPA}

Pengaruh keluarga harmonis dan motivasi belajar tinggi terhadap hasil belajar IPA didapatkan dari analisis regresi berganda. Peneliti menggunakan aplikasi SPSS versi 21 untuk menguji hipotesis penelitian. Berdasarkan analisis, hasil uji $F$ diperoleh nilai $F_{\text {hitung }}$ $>F_{\text {tabel }} I$ sebesar 19,863 > 3,023 dan nilai signifikansi yang diperoleh yaitu 0,000<0,05 yang artinya keluarga harmonis dan motivasi belajar tinggi berpengaruh signifikan secara simultan (bersama-sama) terhadap hasil belajar IPA kelas IV di SDN seKecamatan Kebumen tahun ajaran 2020/2021. Berdasarkan hasil uji korelasi berganda diperoleh $r_{\text {hitung }}=0,961>r_{\text {tabel }}(\mathrm{df}=326)=0,108$ (interval koefisien 0,91 $\left.-0,99\right)$ yang berarti berada pada tingkat hubungan kuat sekali (interval koefisien 0,91-0,99) antara keluarga harmonis dan motivasi belajar tinggi terhadap hasil belajar IPA.

Hasil penelitian ini selaras dengan penelitian yang dilakukan oleh Sulastri (2009) yang melakukan penelitian dengan hasil $F_{\text {hitung }}=6.30$ dan telah dikonsultasikan dengan $F_{\text {tabel }}$ pada taraf signifikansi $5 \%$ ternyata $F_{\text {hitung }}$ lebih besar dari $F_{\text {tabel }}$ atau $6.30>3.96$, jadi ada pengaruh signifikan antara keharmonisan keluarga terhadap prestasi belajar PKn pada siswa kelas VII SLTP Negeri 3 Polokarto Kabupaten Sukoharjo Tahun Ajaran 2007/2008.

Hasil belajar seorang siswa dapat dipengaruhi oleh beberapa faktor yang berperan didalamnya. Menurut Slameto (2010: 54), faktor-faktor yang mempengaruhi hasil belajar digolongkan menjadi dua golongan, yaitu faktor intern dan faktor ekstern. Faktor intern merupakan faktor yang ada dalam diri individu yang sedang belajar, meliputi faktor jasmaniah dan faktor psikologis, sedangkan faktor ekstern adalah faktor yang ada di luar individu yang meliputi faktor keluarga, faktor sekolah dan faktor masyarakat. Dalam 
peneliatian ini, faktor ekternalnya yaitu keluarga harmonis sedangkan faktor internalnya yaitu motivasi belajar tinggi.

Berdasarkan hasil perhitungan yang telah dilakukan, diperoleh nilai koefisien determinasi dalam persen yaitu 92,4\%. Setelah diketahui nilai koefisien determinasi (R2), dilanjutkan mencari sumbangan relatif. Nilai Jkreg sebesar 55506,480 , nilai b sebesar $b=1,049$, dan nilai $c$ sebesar 0,461 , yang kemudian diolah sehingga diperoleh sumbangan relatif keluarga harmonis $72 \%$ dan motivasi belajar tinggi $28 \%$ terhadap hasil belajar IPA. Perhitungan selanjutnya yaitu sumbangan efektif pada keluarga harmonis dapat berperan meningkatkan hasil belajar IPA sebesar $66,5 \%$ dan motivasi belajar tinggi berperan meningkatkan hasl belajar IPA sebesar $25,9 \%$. Hasil sumbangan yang besar menurut peneliti karena merupakan penelitian parsial yang terfokus pada tiga variabel dan juga pelaksanaan pengerjaan soal tes IPA dan angket dikerjakan di rumah.

Berdasarkan penelitian dan pengujian yang telah dilakukan, dapat disimpulkan bahwa keluarga harmonis dan motivasi belajar tinggi berpengaruh positif dan signifikan secara bersama-sama terhadap hasil belajar IPA kelas IV di SDN se-Kecamatan Kebumen tahun ajaran 2020/2021. Sehingga semakin baik keluarga harmonis dan motivasi belajar tinggi siswa, maka semakin baik pula hasil belajar IPA yang didapatkan. Begitupun sebaliknya

\section{SIMPULAN}

Berdasarkan hasil penelitian dan pembahasan mengenai pengaruh keharmonisan keluarga dan motivasi belajar terhadap hasil belajar IPA kelas IV SDN se-Kecamatan Kebumen tahun ajaran 2020/2021 dapat diambil kesimpulan yaitu: (1) adanya pengaruh positif dan signifikan antara keluarga harmonis terhadap hasil belajar IPA; (2) adanya pengaruh positif dan signifikan antara motivasi belajar tinggi terhadap hasil belajar IPA; dan (3) adanya pengaruh positif dan signifikan antara kelurga harmonis dan motivasi belajar tinggi terhadap hasil belajar IPA kelas IV SDN se-Kecamatan Kebumen tahun ajaran 2020/2021.

\section{DAFTAR PUSTAKA}

Ermawati. (2016). Hubungan Antara Keharmonisan Keluarga dengan Perilaku Siswa Sekolah Dasar. Jurnal IImu Pendidikan Sosial, Sains, dan Humaniora. Vol 2 No 3. Guru SD Negeri 002 Muara Lembu.

Hamalik, O. (2015). Kurikulum dan Pembelajaran. Jakarta: PT Bumi Aksara.

Kurnia, Y. P. (2016). Pengaruh Minat dan Motivasi Belajar terhadap Hasil Belajar Seni Musik Siswa Kelas IV SD Dabin I Kecamatan Tondanan Kabupaten Blora. Skripsi Penelitian: Universitas Negeri Semarang.

Marmin. (2013). Kenakalan remaja sebagai permasalahan sosial dan upaya pengatasannya. Jurnal Ilmu-IImu Sosial Dan Humaniora, 1, 1, 1-9.

Nugraheni, R. K. (2014). Pengaruh Peran Orangtua Motivasi Belajar dan Lingkungan Keluarga terhadap Prestasi Belajar Siswa Kelas III SD Se-Gugus Sinduharjo Sleman Tahun Ajaran 2014/2015. Skripsi Penelitian: Universitas PGRI Yogyakarta. Purwanto. (2012). Metodologi Penelitin Kuantitatif. Yogyakarta: Pustaka Pelajar.

Rahmawati, E. (2015). Pengaruh Keharmonisan Keluarga terhadap Hasil Belajar Siswa Kelas V di SD Negeri Kradenan Tahun Ajaran 2014/2015. Skripsi Penitian: Universitas Muhamadiyah Surakarta.

Slameto. (2010). Belajar \& Faktor-faktor yang Mempengaruhinya. Jakarta: Rineka Cipta. Sugiyono. (2013). Metode Penelitian Pendidikan: Pendekatan Kuantitatif, Kualitatif, dan $R \& D$. Bandung: Alfabeta. 
Sulastri, E. (2009). Pengaruh Keharmonisan Keluarga terhadap Prestasi Belajar PKN pada Siswa Kelas VII SLTP Negeri 3 Polokarto Kabupaten Sukoharjo Tahun Ajaran 2007/2008. Skripsi Penelitian: Universitas Sebelas Maret.

Susanti, A. (2015). Pengaruh Motivasi Belajar Siswa Terhadap Prestasi Belajar Matematika Siswa. Jurnal Pendidikan Matematika STKIP PGRI Sidoarjo. Vol 3 No 2, ISSN: 2337-8166. STKIP PGRI Sidoarjo.

Widodo. (2013). Peningkatan Aktivitas Belajar dan Hasil Belajar Siswa dengan Metode Problem Based Learning pada Siswa Kelas VIIA MTs Negeri Donomulyo Kulon Progo Tahun Pelajaran 2012/2013. Jurnal Fisika Indonesia. No 49 Vol XVII, ISSN : 1410-2994. Universitas Ahmad Dahlan. 